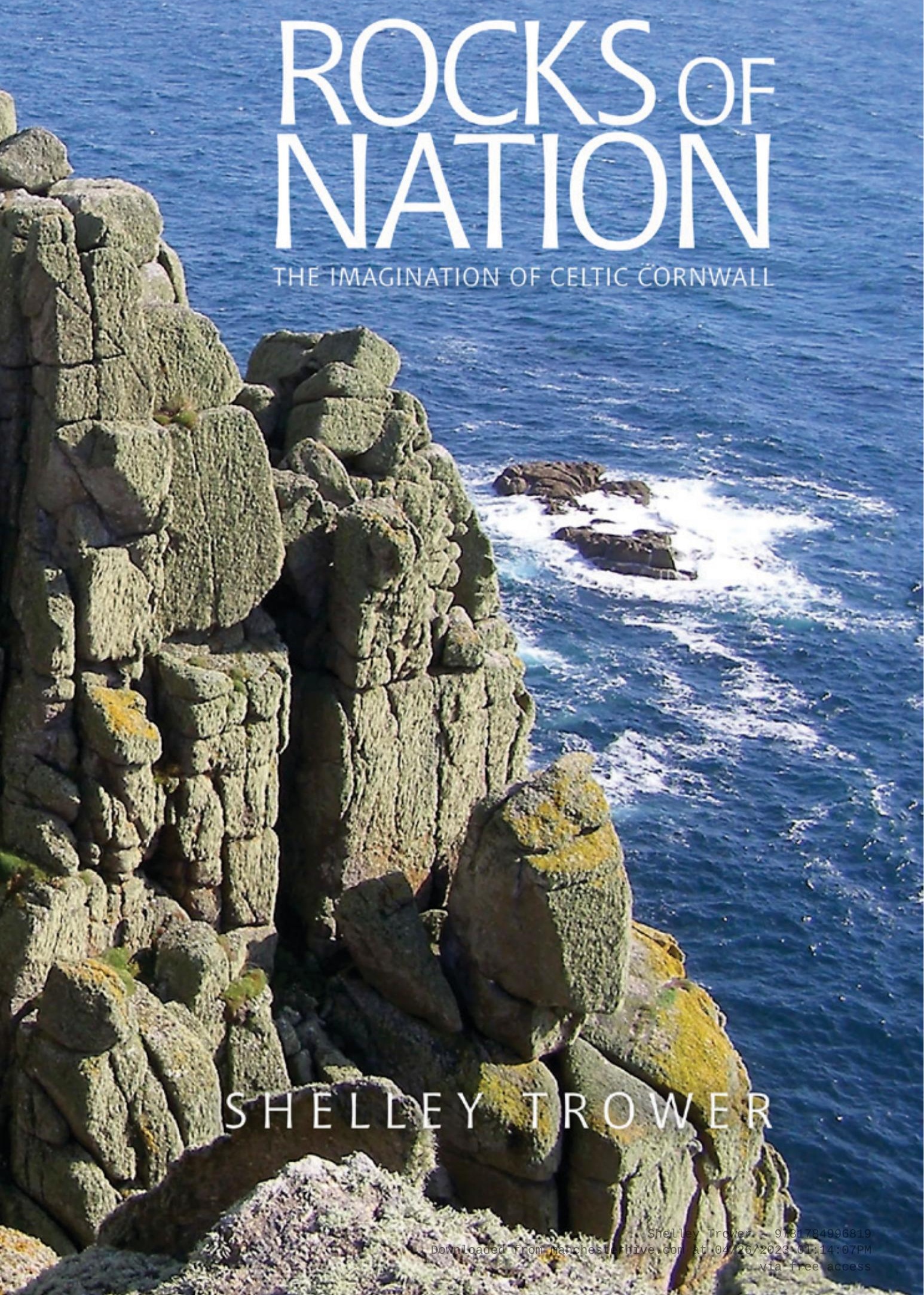




\section{Rocks of nation}

$\infty \infty$

\section{MANCHESTER 1824}

Manchester University Press 


\section{Blank page}




\section{Rocks of nation}

$\infty \infty$

\section{The imagination of Celtic Cornwall}

Shelley Trower

Manchester University Press 
Copyright (C) Shelley Trower 2015

The right of Shelley Trower to be identified as the author of this work has been asserted by her in accordance with the Copyright, Designs and Patents Act 1988.

Published by Manchester University Press

Altrincham Street, Manchester M1 7JA

www.manchesteruniversitypress.co.uk

British Library Cataloguing-in-Publication Data

A catalogue record for this book is available from the British Library

Library of Congress Cataloging-in-Publication Data applied for

ISBN 9780719090967 hardback

First published 2015

The publisher has no responsibility for the persistence or accuracy of URLs for any external or third-party internet websites referred to in this book, and does not guarantee that any content on such websites is, or will remain, accurate or appropriate.

Typeset by Out of House Publishing

Printed in Great Britain by

TJ International Ltd, Padstow 